\title{
Marek Jakubiec
}

Uniwersytet Jagielloński

\section{Dyskurs bioetyczny a postulaty de lege ferenda*}

$18 / 2015$

Political Dialogues

DOI: http://dx.doi.org/10.12775/DP.2015.003

\begin{abstract}
The papers presents the issue of contemporary legal discourse concerning the de lege ferenda propositions. The aim is to display the crucial difficulty of the lawmaking process in the pluralist society. The diversity of bioethical views and inconclusiveness of bioethical discussions causes also legal discourse may be inconclusive. In the article I analyze the issue and formulate some remarks relevant from both the philosophical and practical perspective.
\end{abstract}

\section{Wprowadzenie}

Jedna $z$ dyscyplin, istotnych $z$ punktu widzenia tak filozofii, jak i nauk prawnych jest bioetyka. Jej rola wzrasta wraz $z$ rozwojem techniki, która okazuje się użyteczna w praktyce medycznej i laboratoryjnej $^{1}$. Dzięki nowoczesnym technologiom pojawiaja się nieznane dotąd problemy moralne i dylematy prawne. To $z$ kolei sprawia, że spór o relacje prawa i moralności, będący przedmiotem

* Dziękuję anonimowemu Recenzentowi za wiele cennych uwag i sugestii

1 Ciekawa pozycje poruszajaca zagadnienia rozwoju bioetyki oraz dyskursu bioetycznego stanowi: A. R. Jonsen, The Birth of Bioethics, Oxford University Press, 1998. ożywionej dyskusji w filozofii prawa XX wieku ${ }^{2}$, powraca na nowo, tyle tylko, że w nieco innej formie. Nie tyle idzie bowiem o teoretyczne rozważania dotyczące istoty prawa, a w konsekwencji również i owej relacji, lecz o konieczność praktycznych rozstrzygnięć konkretnych problemów pojawiających się, gdy bioetyka, $z$ jej wieloma odcieniami, styka się $z$ prawem. O ile bowiem indywidualne różnice w tej pierwszej sa w demokratycznym społeczeństwie nieuniknione, o tyle prawo, ze względu na swój uniwersalny charakter, powinno być akceptowalne dla wszystkich, niezależnie od owych dzielacych jednostki różnic.

Okazuje się, że gdy bierzemy pod uwage problemy z zakresu szeroko pojętej bioetyki, osiagnięcie powszechnego konsensu jest niezwykle trudne, a właściwie niemożliwe. W niniejszym artykule przedstawione zostana wybrane aspekty relacji, jaka istnieje pomiędzy dyskursem bioetycznym a prawnym. W szczególności celem tekstu jest wskazanie na istniejące trudności w zakresie analizy propozycji de lege ferenda, dotyczacych kwestii światopoglądowych, czę-

2 Zob. np. J. Raz, The Authority of Law: Essays on Law and Morality, Oxford university Press, 2009; R. Dworkin, Law's Empiry, Hart Publishing Limited, 1998 i wiele innych. 
sto powiazanych $z$ szeroko rozumianymi problemami bioetycznymi. Spojrzenie $z$ perspektywy filozoficznej jawi się jako istotny element rozważań nad tym zagadnieniem.

\section{Normatywność etyki i bioetyki a normatywność prawa - najważniejsze podobieństwa i różnice ${ }^{3}$}

Zarówno etyka, bioetyka jak i prawo to dyscypliny, których zadaniem nie jest dokonywanie $\mathrm{w}$ jak najwyższym stopniu adekwatnego opisu świata, lecz formułowanie wyrażeń preskryptywnych, które maja stanowić wskazania dotyczace ludzkich zachowań. Elementy deskryptywne odgrywaja $w$ nich rolę drugorzędna, choć oczywiście - jako presupozycje sformułowań o charakterze normatywnym - stanowia jednocześnie dla nich swego rodzaju podstawę (przykładem może być następujące założenie, obecne co do zasady w aktach normatywnych: „człowiek jest zdolny do kierowania swymi czynami"). Tym samym, na gruncie logiki klasycznej, nie jest możliwe przypisanie im wartości logicznej (prawdy lub fałszu) ${ }^{4}$. Między innymi ten fakt sprawia, że wyrażenia o charakterze preskryptywnym (będace na przykład dyrektywami etycznymi) niejednokrotnie okazuja się szczególnie kontrowersyjne w pluralistycznym społeczeństwie. W zwiąku $z$ tym, jako uzasadnione jawi się stwierdzenie, że normatywność etyki ograniczona jest do grona osób przyjmujących określony jej system, w zwiazku z czym ma ona charakter ograniczony,

3 Najważniejsze - rzecz jasna $-\mathrm{z}$ punktu widzenia $z$ punktu widzenia tematyki niniejszego tekstu.

4 Zob. J. Jorgensen, Imperatives and Logic, Erkenntnis, 7, 1937/1938, s. $288-290$. partykularny. Tymczasem, prawo pozytywne jako jeden $z$ głównych czynników organizujących społeczeństwo, obowiąuje wszystkie osoby znajdujace się na terenie oddziaływania władzy, która je ustanowiła. Obowiązek przestrzegania norm prawnych jest niezależny od osobistych poglądów jednostki, co wyraźnie odróżnia je od norm etycznych.

\section{Niekonkluzywność dyskursu bioetycznego a pewne postulaty de lege ferenda}

Z powyższych rozważań płynie wniosek, zgodnie $z$ którym w pluralistycznym społeczeństwie mamy do czynienia $z$ napięciem pomiędzy partykularnymi systemami etycznymi a uniwersalnym systemem prawnym. Tym samym, gdy rozważamy relację, jaka istnieje pomiędzy problemami bioetycznymi oraz dotyczacymi ich postulatami de lege ferenda, napięcie to nabiera szczególnego znaczenia $z$ punktu widzenia filozofii prawa.

Jak wspomniano powyżej, powszechny konsens dotyczący problemów bioetycznych jest niezwykle trudny do osiagnięcia. Wynika to przede wszystkim $z$ istoty światopoglądów bioetycznych, a dokładniej $z$ ich źródeł i fundamentów zarazem. Często (o ile nie zawsze) sa nimi określone systemy, które na potrzeby niniejszego tekstu określimy mianem "metafizycznych". Przykładem takiego systemu może być teizm religijny, np. chrześcijański czy judaistyczny. Abstrahując od wielonurtowości współczesnego chrześcijaństwa można stwierdzić, jak się wydaje, że spojrzenie na pewne zagadnienia bioetyczne u osób identyfikujących się $z$ nim sa przezeń wprost wyznaczone. $Z$ podobna sytuacja mamy do czynienia w przypadku ateizmu, który może zawierać w sobie jednocześnie mo- 
nistyczne, materialistyczne spojrzenie na rzeczywistość ${ }^{5}$, którego akceptacja nierzadko wymusza przyjęcie całkowicie odmiennych stanowisk w sprawach światopoglądowych, a co za tym idzie bioetycznych.

Ponieważ owe fundamenty maja charakter ściśle filozoficzny, pytanie o trafność jednego ze stanowisk jest nierozstrzygalne. Idac za rada Poppera, należy stwierdzić, że istotne jest, by kwestie te były dyskutowalne, tym niemniej konkluzywność ewentualnych dyskusji jest $\mathrm{w}$ praktyce nieosiagalna, a argumenty stron sa dla nich wzajemnie niemożliwe do przyjęcia. Nie bez powodu przywołano powyżej spór o istnienie i cechy Boga, niemożliwy do jednoznacznego rozstrzygnięcia, rozumianego jako pewien konsens akceptowalny dla wszystkich jego stron. Okazuje się, że argumenty formułowane przez uczestników dyskursu bioetycznego, jak również - co ważniejsze - prawnego, dotyczacego postulatów zmiany prawa, niejednokrotnie „dziedzicza”" te problemy. Sprawia to, że ów dyskurs staje się ostatecznie jedynie okazja do artykulacji własnych argumentów i wskazania na (rzekome) błędy innych. „Przymus lepszego argumentu”, na którego istotność zwracał uwagę Habermas ${ }^{6}$, nie może mieć w takiej sytuacji miejsca. $Z$ jednej strony pojawia się wszak osoba twierdzaca, że „z pewnościa $\mathrm{p}$, bo r”, $z$ drugiej zaś „z pewnością nie $p$, bo nie jest prawda r”, przy czym za „r” możemy podstawić dowolne zdanie będace implikacja określonego systemu bio-

5 Na marginesie warto oczywiście zauważyć, że nie każdy ateizm musi być tożsamy $\mathrm{z}$ monizmem; idzie tu jedynie o taki, który monizm przyjmuje (zdaje się, że taka jego forma przeważa).

6 Zob. np. J. Habermas, Filozoficzny dyskurs ponowoczesności, przeł. M. Łukasiewicz, Universitas, 2000, s. 153 (choć w nieco innym kontekście). etycznego lub aksjologicznego. W wyniku takiej wymiany zdań dyskutanci nie tylko pozostaja przy swoich stanowiskach (co oczywiście nie jest zjawiskiem negatywnym), ale nie sa w stanie rzetelnie rozważyć argumentów drugiej strony.

Taki stan rzeczy zaś nie tylko nie sprzyja ustaleniu akceptowalnego dla wszystkich stanowiska, które miałoby stać się podstawa stanowionych przepisów prawa, lecz de facto je uniemożliwia. W konsekwencji obywatele skazani sa bąź na brak regulacji prawnej dotyczącej danego zagadnienia bioetycznego, båź też na eskalujące konflikty przepisy uwzględniające jedynie stanowiska osób, których przedstawiciele w chwili stanowienia aktu prawnego posiadali zdobyta w wyborach większość, bądź, co rzadsze, na pewne kompromisy (których ocena przekracza ramy niniejszego tekstu). Co oczywiste, żadna dwóch wymienionych na poczatku sytuacji nie sprzyja budowaniu poszanowaniu dla prawa ani budowie pokojowego współistnienia pomimo dzielących jednostki różnic w ramach jednego społeczeństwa.

$Z$ powyższych analiz zdaje się wypływać następujacy wniosek: uczestnicy dyskursu bioetycznego i prawnego buduja swoja argumentacje bezpośrednio na swoim światopoglądzie etycznym, niejako „zamykając się” na racje innych osób. Jeżeli chcemy poszukiwać źródeł takiej postawy, warto zwrócić uwage na częste absolutne przekonanie o słuszności własnych przekonań i niezdolność do ich rewizji. Zgodnie $z$ teza przedstawiona powyżej, jednym $z$ ich kluczowych elementów jest pewne stanowisko metafizyczne, często nie artykułowane wprost, a nawet nie w pełni uświadamiane. Tym samym, argumenty zostaja oparte na w praktyce niedyskutowalnej - podstawie i okazuja się dla drugiej strony nie- 
możliwe nie tylko do zaakceptowania, ale nawet rozważenia ${ }^{7}$.

Należy w związku $z$ tym postawić pytanie: czy istnieje alternatywa, czyli dyskurs prawny, który nie polega jedynie na wymianie poglądów, nie dajacych się ze soba pogodzić, ale umożliwia poszukiwanie nici porozumienia, bez jednoczesnego wyrzekania się własnych poglądów i bez nielojalności wobec grupy, do której należy jednostka?

Bez watpienia jego przeprowadzenie byłoby trudne, ale wydaje się, że nie niemożliwe. Być może kluczowe okaże się poddawanie analizie przedstawianych bez uprzedzeń i poszukiwanie ich uzasadnienia nie opartego wprost na wyznawanym światopoglądzie. Oczywiście, niezbędne będzie zawieszenie etycznych sądów na określony temat na rzecz logicznie i czysto racjonalnie (z formalnego punktu widzenia) uzasadnionych argumentów (o ich budowie niżej) ${ }^{8}$, które być może zostana przez druga stronę zaakceptowane. Niestety nakłada to na uczestników dyskursu obowiazek merytorycznego przygotowania i dogłębnego przeanalizowania kwestii będacych przedmiotem debaty i niestety od tego zależy, czy będzie ona mogła mieć miejsce. Uzasadnione wydaja się obawy, że dla dużej części obywateli państw demokratycznych będzie to niezwykle trudne. Watpliwości może również budzić pytanie, czy uczestnicy będa chcieli dostosować swoja argumentację i sposoby przeprowadzania rozumowań do wskazywanych w tym tekście lub podobnych wymogów, a mo-

$7 \mathrm{~W}$ tej kwestii zob. również: M. Jakubiec, Doktryny religijne a stanowienie prawa $\mathrm{w}$ dobie światopoglądowego pluralizmu, Acta Erasmiana, 8, 2015, s. 232-233.

8 Tamże. Warto zauważyć, że argumenty te wcale nie musza co do istoty różnić się od argumentów etycznych (w pewnych przypadkach być może nawet nie powinny). deratorzy dyskusji (obecnie rolę tę pełnią głównie dziennikarze) zechca dążyć do przestrzegania określonych reguł i standardów. Kwestia ta wymaga bez wattpienia dokładniejszych analiz.

W celu zobrazowania powyżej wskazanej propozycji, warto posłużyć się prostym, ale jednocześnie wywołującym wiele kontrowersji przykładem, który stanowi problem prawnej regulacji aborcji. Należy zastrzec, że posłużymy się tu pewną idealizacją, współczesnego społeczeństwa nie sposób wszak uznać za agorę, zapewniajaca nieskrępowane prowadzenie dyskusji stanowiacych podstawę decyzji ustawodawcy.

Wydaje się, że dopóki dyskusja na ten temat będzie skoncentrowana na argumentach światopogladdowych, rozwiązanie problemu będzie niemożliwe i skazani będziemy badź to na dyktaturę większości bądź na niedoskonałe, wciąż podważane kompromisy. Jeżeli natomiast, uznając (chwilowo), że nie jest możliwe osiagnięcie akceptowanego przez wszystkich konsensu co do ustalenia momentu, od którego należy chronić ludzkie życie, podejmiemy próbę przedstawienia argumentacji przemawiajacej za naszym stanowiskiem, być może pozostali jego uczestnicy będa skłonni uznać jej sen sowność. To z kolei jawi się jako warunek rzeczywistej dyskusji nad przedstawianymi argumentami. Nawet jeżeli dyskutanci tego nie uczynia, taka zmiana $z$ pewnościa wpłynie pozytywnie na język publicznej debaty. W jaki sposób taka argumentacja mogłaby wyglacdać?

Przykładowo, uczestnicy dyskursu obowiązani sa nie stosować następujących argumentów: przeciwko prawnej dopuszczalności aborcji tożsamego $z$ religijnie umotywowanym przekonaniem o konieczności ochrony ludzkiego życia od poczęcia i umotywowanego jedynie 
tym przekonaniem lub argumentu za wprowadzeniem dopuszczalności tejże, wprost wynikajacego $z$ wyznawanego światopoglądu bioetycznego, w którym na ochronę zasługuja jedynie osoby posiadajace w pełni rozwinięta świadomość, który to światopogląd stanowi jedyne merytoryczne ugruntowanie głoszonych propozycji. Moga one być odrzucone przez druga stronę $z$ powodu niepodzielania poglądów religijnych i światopoglądowych, bez ich pogłębionej analizy.

W związku $z$ tym na początku warto na przykład przedstawić punkty, co do których panuje powszechna zgoda, a następnie wskazywać, w jaki sposób konkretne stanowisko jest ich konsekwencja. W przypadku osoby co do zasady przeciwnej prawnej dopuszczalności aborcji mogłyby one wyglądać podobnie do tych przedstawionych poniżej ${ }^{9}$ :

1. nie mamy jednej koncepcji dotyczaccej prawnej regulacji poczatku ochrony ludzkiego życia, akceptowanej przez nas wszystkich;

2. tym niemniej ludzkie życie zasługuje na ochronę;

3. jeżeli tak, to na ochronę zasługuje nie tylko życie znajdujace się w stadium „aktualności”, lecz także „życie potencjalne” - czyli formy, $z$ których życie ludzkie powstaje w przyszłości; zniszczenie tych form powoduje bowiem $\mathrm{w}$ istocie zniszczenie życia - co do ochrony którego panuje zgoda;

4. w związku $z$ tym należy również chronić życie zarodków.

9 O podobnym zagadnieniu w kontekście problematyki dyskursu religijnego pisałem w: M. Jakubiec, Doktryny religijne a stanowienie prawa $\mathrm{w}$ dobie światopoglądowego pluralizmu, dz. cyt., s. 233-234.
Jest to oczywiście pewne uproszczenie, konieczne jednak, by ominać szczegółową analizę problemu aborcji, na która w niniejszym tekście nie ma miejsca. Nie oznacza to oczywiście przezwyciężenia niekonkluzywności dyskursu bioetycznego. Jak wspomnieliśmy powyżej, dyskurs prawny, gdy dotyczy kwestii powiązanych $z$ bioetyka, dziedziczy tę trudność. Nie jest to również rozumowanie pozbawione niedoskonałości, gdyż zawiera błą non sequitur $z$ przesłanek 1 . i 2 . nie wynika wniosek 3., a tym samym również 4 (tym bardziej, że stanowi wyrażenie w pełni preskryptywne). Zadaniem drugiej strony będzie więc wskazanie na ten błąd, a dla autora rozumowania może to stanowić okazję do refleksji nad własnym stanowiskiem i poszukiwania innych, bardziej doskonałych linii argumentacyjnych. Nie zmienia to jednak faktu, iż idea ochrony „życia potencjalnego” może stać się istotnym elementem w dyskusji, a jeśli strony będą koncentrować się na poszukiwaniu właściwej definicji czy podejma dyskusję nad przedstawianymi rozumowaniami, to zdecydowanie uczyni to dyskurs prawny bardziej racjonalnym i lepiej służacym przyszłym zmianom prawa. Zamiast prowadzić spór o enigmatyczny początek życia czy moment od którego możemy mówić o godności człowieka (co wynika u bardzo wielu obywateli wprost $z$ wyzwanego światopoglądu) rozpoczynamy dyskusję na nieco innym poziomie.

Powyższy zarys propozycji racjonalizacji dyskursu ma zmniejszyć jego problematyczność poprzez częściowe uwolnienie go od nierozstrzygalnych problemów filozoficznych. Zamiast poszukiwania nieosiagalnej odpowiedzi, które stanowisko metafizyczne jest trafne, próbujemy osiagnąć konsens możliwy do wdrożenia w przepi- 
sach prawnych, owo niezwykle istotne poszukiwanie pozostawiajac na czas dyskursu ściśle bioetycznego i filozoficznego.

Możliwość wcielenia tej i podobnych propozycji w życie jest oczywiście problematyczna, choćby $z$ racji faktu, że już pobieżne spojrzenie na dyskurs prawny we współczesnych demokracjach ukazuje, iż głównym celem mediów i polityków jest oddziaływanie na emocje obywateli. Trudna dyskusja na wysokim poziomie merytorycznym nierzadko umyka uwadze mediów, podczas gdy pełen emocji przekaz nader często zajmuje kluczowe miejsce w ich przekazie.

Tym niemniej, jeżeli każda strona będzie zobowiazana do wykazania swojego stanowiska na drodze argumentów nie uzasadnianych jedynie w oparciu o stanowisko bioetyczne, dyskurs prawny stanie się $z$ pewnościa bardziej otwarty, nawet jeśli nie doprowadzi do wypracowania wspólnych postulatów prawnych.

Zmiana poziomu językowego $z$ emocjonalnego na bardziej abstrakcyjny nie jest, co oczywiste rozwiazaniem przedstawionych problemów. Trudno przewidzieć, czy mogłaby się przysłużyć procesowi stanowienia prawa - ale z pewnościa takie, choćby częściowe, „uracjonalnienie” dyskursu pozwoliłoby zobaczyć pluralizm w kwestiach bioetycznych niekoniecznie jako czynnik wyłącznie destrukcyjny gdy idzie o stanowienie prawa. W dobie ogromnych podziałów, $z$ jakimi mamy obecnie do czynienia w Polsce wydaje się propozycja co najmniej surrealistyczną. Być może jednak w przyszłości podobne spojrzenie pozwoli nam w sposób bardziej racjonalny tworzyć normy prawne i budować aspekty wspólnej, społecznej rzeczywistości.
W ostatniej części spróbujemy spojrzeć na zagadnienie dyskursu bioetycznego i prawnego $z$ perspektywy proceduralnej. O ile dotychczas zajmowaliśmy się merytorycznymi aspektami argumentacji jego uczestników, o tyle teraz rozważymy w jaki sposób powinien on przebiegać $z$ formalnego punktu widzenia.

\section{Kwestie proceduralne}

Jak uznaliśmy powyżej, konkluzywny dyskurs bioetyczny jest niezwykle trudny do osiagnięcia (o ile w ogóle możliwy), co przekłada się bezpośrednio na problem niekonkluzywności dyskursu prawnego, w szczególności dotyczacego kontrowersyjnych postulatów de lege ferenda. Nie oznacza to jednak, że nie powinniśmy dażyć do „zwiększenia” stopnia konkluzywności oraz racjonalności dyskursu, $z$ jakim mamy do czynienia w czasie debat dotyczacych prawnych regulacji kwestii bioetycznych. Wydaje się, że można sformułować propozycję pewnych czysto formalnych warunków, które powinny spełniać wypowiedzi wszystkich jego uczestników, reprezentujacych możliwie szeroko społeczna mozaike światopoglądową. Próbowali tego dokonać liczni myśliciele; w tym miejscu przypomnijmy krótko koncepcje dwóch $\mathrm{z}$ nich: J. Habermasa i R. Alexy'ego.

Habermas znany jest między innymi ze stworzenia koncepcji „idealnej sytuacji mowy"(ideale Sprechsituazion) ${ }^{10}$. Aby takowa zaistniała, winien być spełniony szereg warunków, m. in. jednakowe dla każdego, kto może stać się uczestnikiem dyskursu możliwości wykonywania ak-

10 Habermas pisze o swojej propozycji w wielu miejscach, podejmuje próbę jej zdefiniowania np. w: J. Habermas, Vorstudien und Ergänzungen zur Theorie des kommunikativen Handelns, Suhrkamp Verlag, Frankfurt am Main 1984, s.180. 
tów językowych, równe szanse przedstawiania swoich tez i krytyki tez prezentowanych przez innych uczestników, żadne ze stwierdzeń nie powinno zostać wyłączone $z$ możliwości dyskursu, uczestnicy dyskursu moga wyrażać jedynie własne, rzeczywiste intencje ${ }^{11}$. Alexy natomiast, uznając, że dyskurs prawny stanowi szczególny przypadek dyskursu ogólnego, przedstawia szczegółowe normy, do spełnienia których zobowiązani sa jego uczestnicy ${ }^{12}$. Najważniejsze $z$ nich to ${ }^{13}$ :

- żaden mówca nie może przeczyć sam sobie,

- mówca może bronić jedynie tego, w co sam wierzy,

- każdy mówca, który stosuje określony predykat do danego obiektu musi być gotowy do zastosowania go również wobec każdego innego obiektu, wykazującego się takimi samymi cechami,

- mówcy nie moga używać tego samego słowa w różnych znaczeniach.

Istotna jest również powszechność (egalitarność) dyskursu - w opinii Alexy'ego każdy, kto posiada umiejętność poprawnego posługiwania się językiem, powinien mieć zapewniona możliwość uczestniczenia w nim ${ }^{14}$.

11 Zob. L. Morawski, Główne problemy wspótczesnej filozofii prawa. Prawo $w$ toku przemian, PWN, Warszawa 1999, s. $150-151$.

$12 \mathrm{Na}$ marginesie należy zauważyć, że w ujęciu Alexy'ego dyskurs dotyczacy prawa ma za zadanie przede wszystkim uzasadnienie czy usprawiedliwienie rozstrzygnięć dokonywanych przez sądy, a więc szczególnego typu wypowiedzi o charakterze normatywnym. Tym niemniej przedstawione przez niego dyrektywy bez watpienia maja znaczenie również dla teorii dyskursu dotyczacego postulatów de lege ferenda.

13 R. Alexy, A Theory of Legal Argumentation, Oxford University Press, 2009 (za: J. Stelmach, R. Sarkowicz, Filozofia prawa XIX i XX wieku, Wydawnictwo Uniwersytetu Jagiellońskiego, Kraków 1999, s. 153).

14 B. Brożek, The Weight Formula and Argu-
Zważając na powyższe uwagi można pokusić się o sformułowanie następujących kilku dyrektyw argumentacyjnych, dotyczacych językowych ekspresji przedstawianych stanowisk ${ }^{15}$

1) pozbawione sa, na ile jest to możliwe, błędów, tj. sa niesprzeczne w jak największym stopniu oraz nie zawieraja błędnych wniosków, wyciaganych na podstawie określonych przesłanek (nieco uszczegółowiony warunek przedstawiony przez Alexy'ego),

2) nie używaja znanych pojęć w zmienionym znaczeniu,

3) nie sa oparte na uproszczeniach, tj. redukcjonistycznych pogladach na określone zagadnienia oraz pozbawione błędów performatywnych,

4) nie zmierzaja do wywołania negatywnych emocji u interlokutora ani do jego ośmieszenia, (jak np. argumenty ad personam lub skierowane do grupy, która dyskutant reprezentuje),

5) nie zmierzaja do wywołania określonych emocji u słuchaczy (przyjmujemy tu założenie, że emocje sa w dużej części irracjonalne) ${ }^{16}$.

W powiązaniu $z$ warunkami przedstawianymi m.in. przez R. Alexy'ego i J. Habermasa (z którymi częściowo sa tożsame) jawia się one jako subminimalne dyrektywy skierowane do uczestników dyskursu prawnego, majace zapewnić

mentation [w:] Law, Rights and Discourse: The Legal Philosophy of Robert Alexy, G. Pavlakos (ed.), Hart Publishing, Oxford 2007, s. 320.

15 Szerzej na ich temat pisałem a tekście M. Jakubiec, Nieracjonalność dyskursu prawnego $w$ świetle teorii Roberta Alexy'ego [w:] Społeczeństwo rozumne?, red. K. Cikała, W. Zieliński, K. Drą̇kiewicz, WN UPJPII, Kraków 2013, s. 134. Niniejszy fragment rozważań oparty jest na treści tego artykułu.

16 Tamże. 
„Zwiększenie poziomu” jego racjonalności, a w rezultacie również i konkluzywności.

Na zakończenie zwróćmy uwage na kilkakrotnie użyte w tekście pojęcie „racjonalności" i rozważmy, w jaki sposób zdefiniować ja, aby żadna ze stron nie była de facto przez tę definicje $z$ dyskursu wyłączona. Dotychczas w kontekście dyskursu dotyczącego postulatów de lege ferenda rozważaliśmy zagadnienie jego konkluzywności, tym niemniej racjonalność jako problem o wiele bardziej złożony domaga się krótkiego zaznaczenia, przy zastrzeżeniu, że będzie ono miało charakter jedynie sygnalizacyjny.

Pojęcie racjonalności jest niezwykle wieloznaczne. Podejmując próbę zdefiniowania „racjonalnego dyskursu” musimy w zwiazku z tym ograniczyć się do pewnej konwencji. W kontekście dyskursu prawnego wydaje się, że definicja mogłaby przyjąc następujące brzmienie: „racjonalny dyskurs to taki, w którym kluczowa rolę odgrywaja argumenty oparte na możliwie spójnym rozumowaniu, pozbawionym uproszczeń i błędów logicznych". W zwiazku $z$ tym nasuwa się kilka krótkich uwag.

Racjonalność jawi się jako jedno z kluczowych $z$ socjologicznego punktu widzenia kryteriów sensowności wypowiedzi dotyczących różnych tematów $\mathrm{w}$ pluralistycznym społeczeństwie. Pluralizm jest również jedna $z$ najistotniejszych zasad demokratycznego państwa prawnego ${ }^{17}$. $Z$ interesujacego nas punktu widzenia znaczenie fundamentalne ma poszanowanie różnic, jakie występuja między obywatelami w sferze ich światopoglądów, ze względu na fakt, że nie jest dziś możliwe wskazanie podzielanego przez wszystkich obywateli ja-

17 Zob. art. 11, 12, 13, 14 Konstytucji RP (Dz. U. z 1997 r. Nr 78, poz. 483). kiegokolwiek państwa demokratycznego całościowego systemu bioetycznego czy aksjologicznego. W zwiazku $z$ tym brak jest powszechnie przyjmowanych kryteriów pozwalających jednoznacznie ocenić, który $z$ wielu jest właściwy. Stąd konieczność maksymalnej racjonalizacji (w powyższym sensie) dyskursu prawnego. Po drugie, powtórzmy, jedna $z$ najistotniejszych dziedzin regulujacych życie publiczne w państwie demokratycznym jest prawo. Obowiazek jego respektowania spoczywa bowiem na wszystkich obywatelach, niezależnie od ich osobistych zapatrywań na poszczególne sytuacje uregulowane prawnie ${ }^{18}$.

Wydaje się, iż już dwie przedstawione powyżej uwagi wystarcza do stwierdzenia, że dażenie do maksymalizacji racjonalności dyskursu prawnego jest koniecznością. Podobnie jak w jak największym stopniu konkluzywny, również i w jak największym stopniu racjonalny dyskurs prawny winien on być podstawa decyzji podejmowanych przez przedstawicieli władzy publicznej.

\section{Podsumowanie}

Z powyższych rozważań wyłaniaja dwa zasadnicze wnioski: po pierwsze, niekonkluzywność jako cecha dyskursu bioetycznego przekłada się na problemy dyskursu w kwestii postulatów de lege ferenda, powiazanych $z$ zagadnieniami zwiazanymi $z$ bioetyka. Po drugie, zmiana sposobu argumentacji, poprzez nie odwoływanie się jedynie do argumentów wynikajacych wprost $z$ systemu przekonań światopoglądowych, jak również stosowanie się pewnych dyrektyw proceduralnych może stanowić drogę do

18 M. Jakubiec, Nieracjonalność dyskursu prawnego $w$ świetle teorii Roberta Alexy'ego, dz. cyt., s. 131. 
zwiększenia zarówno konkluzywności, jak i racjonalności dyskursu prawnego, który winien stanowić podstawę decyzji dotyczacych stanowionego prawa.

\section{Bibliografia}

Alexy R., A Theory of Legal Argumentation, Oxford University Press, 2009.

Brożek B., The Weight Formula and Argumentation [w:] Law, Rights and Discourse: The Legal Philosophy of Robert Ale$x y$, G. Pavlakos (ed.), Hart Publishing, Oxford 2007.

Habermas J., Filozoficzny dyskurs ponowoczesności, przeł. M. Łukasiewicz, Universitas, 2000.

Habermas J., Vorstudien und Ergänzungen zur Theorie des kommunikativen Handelns, Suhrkamp Verlag, Frankfurt am Main 1984, s.180.
Jakubiec M., Doktryny religijne a stanowienie prawa w dobie światopogladowego pluralizmu, Acta Erasmiana, 8, 2015.

Jakubiec M., Nieracjonalność dyskursu prawnego $w$ świetle teorii Roberta Alexy'ego [w:] Spoleczeństwo rozumne?, red. K. Cikała, W. Zieliński, K. Drążkiewicz, WN UPJPII, Kraków 2013.

Jonsen A.R., The Birth of Bioethics, Oxford University Press, 1998.

Jorgensen J., Imperatives and Logic, Erkenntnis, 7, 1937/1938.

Morawski L., Główne problemy współczesnej filozofii prawa. Prawo $w$ toku przemian, PWN, Warszawa 1999.

Stelmach J., Sarkowicz R., Filozofia prawa XIX i XX wieku, Wydawnictwo Uniwersytetu Jagiellońskiego, Kraków 1999. 